\title{
China's pragmatic experimentalism towards sustainable transition: Wind power and Sino-Danish collaboration
}

Julia Kirch Kirkegaard' and Rongping $\mathrm{Mu}^{2}$

'Department of Wind Energy, Technical University of Denmark; ' Institute of Policy and Management, Chinese Academy of Sciences

The boom, bust and re-emergence of China's wind power market

China has in recent years astonished the world with its rapid emergence as a new global 'green leader'. No other sector has demonstrated China's capability of rapid industrial upgrading and catch-up in the green sector better than wind power (Mathews and Tan 2014; Lewis 2013; Korsnes 2014; Kirkegaard 2015; Delman 2020).

This transformation has been enabled through adaptive changes in Chinese policies and pragmatic governance of Sino-foreign relations. China started experimenting with wind resource mapping in the 1980s. However, the country's early adventures in wind power were marked by a series of fragmented and scattered experiments, plagued by indecisiveness and ambivalence as to whether to make a coordinated and focused effort to nurture Chinese manufacturing capabilities in this area. It was only relatively late that China decided to enter the wind power market, but it proved to be a grand entry. With the implementation of the Renewable Energy Law (2005/2006), China's wind turbine industry immediately started to grow at an unprecedented pace. China rapidly became the world's largest wind power market in terms of installed capacity: China's installed wind power capacity was only 0.8 Gigawatts (GW) in 2004 but reached around 45 GW by 2010, making China the world leader in total installed capacity, a position it still holds with $234 \mathrm{GW}$ installed by the end of 2019 (Andrews-Speed 2012; GWEC 2020; Lewis 2007, 2013; Klagge et al. 2012; Kirkegaard 2019; Lema and Ruby 2007; Zhao et al. 2012). At the same time, Chinese wind turbine manufacturers emerged in large numbers, including Goldwind, Sinovel and Envision (Lewis 2013; Kirkegaard 2015). Meanwhile, the rapid boom in installed capacity caused a host of problems, particularly in terms of wind turbine quality, high rates of wind power curtailment and a significant number of wind turbines that were not connected to the grid. However, through agile government intervention in energy and science, technology and innovation. China's wind turbine industry was rapidly steered from a trajectory of upscaling and poor quality towards one of upgrading and an agile 'turn to quality' (Kirkegaard 2019).
Today, China is greening its electrical power sector at an unprecedented rate through world record investments in renewable energy, and particularly in wind power. As a recent sign of its serious intent, China's proclaimed 'Energy Revolution' (néngyuán gémìng, 能 源革命) strategy lays out the clear ambition to strengthen grid capacity, expand distributed generation and improve the integration of renewable energy into the electrical power system (Chung and Xu 2016; Communist Party of China Central Committee and the State Council 2015; Dupuy 2016; Liu and Kong 2016; NEA 2015; Kirkegaard 2019)

Based on interviews with industry and policy actors, and document analysis, in China and Denmark - particularly the analysis of Kirkegaard $(2015,2017,2019)$ - around China's wind power sector, we show how China's entry onto the global wind power stage has followed a cycle of boom, bust and re-emergence. China's emergence has been framed and mobilised through a distinct 'Chinese fragmented authoritarianism' (Kirkegaard 2019; Kirkegaard and Caliskan 2018) and a particular mode of Chinese innovation that allows for experimental trial-and-error at the meso-level, while simultaneously allowing unforeseen technological issues in wind turbines to quickly materialize. This has at times necessitated prompt government action, and has facilitated accelerated learning and innovation (Kirkegaard 2019). This empirical context sets the scene to explain the implications for Sino-Foreign, or in this case, Sino-Danish, collaborations.

\section{Understanding the rollercoaster journey of Chinese wind power through pragmatic experimentalism}

The early rise of China's wind turbine industry and wind power market materialized through a substantial reliance on Foreign Direct Investments (FDI) that ensured technology transfer. China's 'trade-market-access-for-technology' strategy has helped to attract foreign companies to China, e.g. assisted by the local content requirements, which pushed foreign companies to set up manufacturing in China in order to be able to access the Chinese market. This was already seen in the Ride the Wind Programme (1996) and later 
in Chinese state concessions for wind power development in the early 2000s, with the evaluation criteria requiring a certain amount of the equipment to be produced in China (Lewis 2013). The industry-oriented policy of local content requirement was abolished in 2009, but by this point almost all Western wind turbine companies had already set up manufacturing in China. In particular, the Ride the Wind Programme (1996) promoted the formation of Sino-foreign joint ventures, and over time, foreign companies were attracted by the vast size of China's market. Major foreign wind turbine manufacturers operating in China include the Danish company, Vestas, as well as Suzlon, Gamesa and, more recently, General Electric and Siemens (Lewis 2013; REN21 2009a in García 2013; Gosens and Lu 2013; Zhao et al. 2012b). Component suppliers and emerging suppliers of Knowledge-Intensive Business Services (KIBS) (Schmitz and Stramback 2009; Haakonsson et al. 2020) have provided expertise across multiple areas, such as software tools for certification and design. Many of these foreign suppliers are Danish (e.g. Mita Teknik, DEIF) and have contributed substantially to the rapid catch up of Chinese wind turbine manufacturers and component suppliers. This input has been supplemented by other financial instruments that helped to build up an industrial base and attract both FDI and the localization of foreign companies in China by means of economic incentives, such as lower import tariffs for renewable energy equipment, investment and R\&D subsidies, tax breaks and favourable pricing.

Learning from technology and knowledge transfer, the Chinese wind turbine industry was soon in a position to undercut Western manufacturers. Around 2010, however, the industry began to witness 'frequent reports of quality problems and technical difficulties of domestically manufactured wind turbines', such as fractures of blades and shafts, generator fires, gearbox ruptures and brake failures (Lian and Wu 2011 in Klagge et al. 2012:376). Consequently, Chinese wind turbine manufacturers struggled to secure international certification. While China had been able to produce wind turbines at a much lower price than the least expensive models offered by their foreign competitors (Nahm and Steinfeld 2014), the central government's 'preference of industry creation, and hence quantity before quality' (Korsnes 2014:192) had created massive quality problems in terms of underperformance, both of wind power generation and average annual wind utilisation. This poor performance was reflected in component failures, low capacity, an inability to connect to the grid and even major accidents (Cherni and Kentish 2007; García 2013; Gosens and Lu 2014; Kirkegaard 2015, 2019; Klagge et al. 2012; Lewis and Wiser 2007). It became clear that many wind farms in China were not generating the energy that was expected from wind farms of their installed capacity. Soon the industry was suffering from an overheated wind power sector, with abundant overcapacity, increased competitive tension between Chinese and foreign industry actors, as well as difficulties in achieving international certification and fulfilling export ambitions. While the reasons behind these problems were manifold, they were primarily related to fragmented planning and coordination between local and central spheres, policies that emphasized price over quality, targets for installed capacity (Gigawatt/GW) instead of generated electricity (Gigawatt/hour), a lack of certification requirements (Kirkegaard 2015, 2019) and a focus on applied science over basic research in STI policies (Cao 2004).

What is more interesting than the 'bust', however, is the impressive capability of the Chinese government, by means of agile policy adjustments, to steer the sector through the crisis towards a 'recovery' that has reinstalled China as a leading wind power nation, as well as one that increasingly competes and collaborates at an equal level with foreign counterparts that have benefitted from a much longer experience of working with wind turbine technology and integration. To resolve the quality crisis, the wind power sector was steered by government interventions to fine-tune turbine technology (though higher focus on quality and basic research) and to upgrade core technologies and develop indigenous designs, addressing risk and uncertainty through enhanced emphasis on certification and standardisation.

This push for 'Scientific Development' to 'recover' the sector has been nurtured, since 2012, by central government policies, plans, standards, targets and regulations, together instigating an imminent potential 'turn to quality' (Kirkegaard 2015, 2019). This was particularly corroborated in the 12th Five-Year Plan for the Scientific and Technological Development of Wind Power (2012, State Council and Ministry of Science 8 Technology (MOST)). The strengthened focus on quality was reiterated in China's 13th Five-Year-Plan (2016-2020) and the imminent Energy Revolution (2015), where focus shifted from capacity expansion towards quality and efficiency. Central to this transformation was the Medium- to Long-Term Plan for Scientific \& Technological Development (MLP 2006-2020), which introduced the notion of 'indigenous innovation', and has been restated and further elaborated through a number of policies, plans and strategies. Other major interventions included the introduction of stricter standards and certification requirements (Lewis 2013; Kirkegaard 2019; Ernst 2013); targets for generated electricity (García 2013; Lema and Ruby 2007:3888; Liu and Kokko 2010:5524; Bloomberg 2012; Korsnes 2014); enhanced

1 The influential notion of the term 'scientific development(alism)' (kēxué fāzhăn guān, 科学发展) was first introduced in 2003 by President Hu Jintao (Christensen 2013:85-86), and later enshrined in Chinese Commu nist Party (CCP) doctrines, which marked its legitimisation (Christensen 2013:86). To achieve scientific development, the development of indigenous innovation capabilities (Zìzhǔ chuàngxīn, 自主创新) in science, research and within core technologies has been construed as indispensable (Andrews-Speed 2012; Christensen 2013; Fan 2006:709-717; Lewis 2013; Mathews and Tan 2015; Meidan, Andrews-Speed and Xin 2009). 
incentives for turbine quality (e.g. through energy pricing and financial support schemes) (Kirkegaard and Caliskan 2018; García 2013; Zhao et al. 2012:228); centralisation of control and planning (Korsnes 2014; Lewis 2013:74; Kirkegaard 2019); and upgrading of core technologies, such as control system software and simulation tools for design and certification (Kirkegaard 2019; Haakonsson et al. 2020). Indigenous innovation in core technologies has also been critical for success in instigating a 'turn to quality', and for getting the industry back on track (12th Five-Year Plan for the Scientific and Technological Development of Wind Power, MOST 2012).

Through the process of 'boom-bust-and-recovery' and in line with China's fragmented authoritarianism (Lieberthal 2004), the Chinese government has oscillated between what can be termed 'decentralised fragmentation' and 'centralised authority', in order to achieve development targets (Lieberthal 2004; Andrews-Speed 2012). Decentralisation of authority (or 'decentralised fragmentation'), in terms of approvals of new wind farms, alongside a certain ambiguity in terms of implementation of targets, has been beneficial for the period of accelerated growth in the wind industry, while centralisation of authority, in 2011, was aimed at slowing growth in a period of severe overcapacity (Andrews-Speed 2012; Korsnes 2014:196; Breznitz and Murphree 2011; Kirkegaard 2015, 2019). What seems even more intriguing is how, somewhat paradoxically, it appears that the quality issues that had surfaced in China's wind turbine industry were pragmatically allowed by the state. This transpired through permitting local provinces and wind farm developers to develop and experiment with wind turbine technology innovation and wind farm development without central control. This, in turn, produced a number of technological quality issues to quickly emerge, while the central government did not intervene until the very last minute. Even though the Chinese state may not have intended to induce the number of quality issues that surfaced, it also did nothing to prevent them from happening until the brink of collapse. This strategy is linked to learning through 'failure' rather than cracking down on it from the outset (Kirkegaard 2019). It also relates to a particular mode of 'innovation' at the meso-scale (Kirkegaard 2019), enabled through a process of "pragmatic, interactional, adaptive, solution-oriented collaborative efforts [between Chinese and foreign actors] (Delman 2020:1) that has enabled the adaptive governance and readjustment of Chinese energy and STI policies."

\section{Discussion: The role of Sino-foreign (Sino-Danish) collaboration in wind power - and future prospects}

From the context set out, we discuss prospects for Sino-foreign collaborations in wind power.

The impressive - but bumpy - development of China's wind power market cannot be understood without an appreciation of the contribution of technology and knowledge transfer. Sino-foreign collaborations have played an indispensable part in China's upgrading of its wind turbine industry. In particular, Denmark has played a critical role: Sino-Danish collaborations in the area have a long history, starting with the National Laboratory for Renewable Energy, Risø (now under the Technical University of Denmark, the Department of Wind Energy), with scientists being sent to China to assist in the mapping of wind resources - a collaboration that has continued for many years.

Diplomatic-Scientific relations between China and Denmark have also been strong in the wind power field. Under the Sino-Danish Renewable Energy Development Programme (RED) (2009-2013) - jointly developed by the Chinese and Danish governments and comprising two components (the development of the China National Renewable Energy Centre (CNREC) in Beijing and joint Sino-Danish renewable energy projects) - projects in wind turbine testing and certifcation, among others, have taken place. In 2012, the Chinese energy authorities officially opened CNREC in close collaboration with the Danish Energy Agency, working together on developing strategic energy policies, state-of-the-art methodologies and tools to encourage the use of renewable energy in the Chinese energy system, leveraging Denmark's Iong experience with and approach to energy system planning. Over time, CNREC has become a major resource for Chinese policy makers seeking expert advice and analysis on renewable energy (ens.dk; Kirkegaard 2019). Overall, China's wind power sector has developed through a close collaboration between Chinese authorities and energy policy actors with international partners (Delman 2020; Lewis 2013; Kirkegaard 2015), as Denmark represents "a best-practice learning case, and through a strategic government-to-government partnership, [Denmark] has gradually become one of China's preferred strategic policy interlocutors on energy politics" (Delman 2020:1).

In addition to diplomatic collaborations, the rapid upgrading of Chinese wind turbine manufacturers - such as Goldwind, Envision and Mingyang, which have emerged as new 'Dragon Multinationals' (Mathews 2016) - cannot be understood without considering them in the light of China's integration into global innovation networks. These Chinese companies are increasingly able to manufacture competitive, state-of-the-art wind turbine systems, and claim to be integrated into global learning and innovation networks as they experiment with control system software, indigenous (homegrown) designs and software applications (interviews; Lewis 2007, 2013:166; Mathews 2016; Silva and Klagge 2013). As Mathews and Tan (2015) have argued, China may well be able to make renewable energy and low-carbon technologies 'synonymous with its own industrial revolution', simultaneously 'breaking the "carbon lock-in" that has delayed the energy revolution in other developed 
countries' (Mathews and Tan 2015:148), while moving beyond its current stage as the 'world's factory'. China's rapid upgrading has also seen the strategic use of KIBS, which have adopted a business model focused on licensing out technologies (Haakonsson et al. 2020), a trend that reached China along with the more generic organizational decomposition of innovation processes (ODIP) (Strambach 2008).

For many years, however, both Sino-Danish and Sino-Foreign supply chain relations were marked by a one-way technology transfer, backed by China's renowned and notorious strategy of 'trade market access for technology strategy'. Built on the idea of tapping into foreign technologies and innovation (Klagge et al. 2012) through a linking-leverage-learning strategy (Mathews 2002), Chinese companies and research institutes integrated themselves into global value chains and increasingly into global learning (Lewis 2013) and innovation networks (Kirkegaard 2015). Taking advantage of the impetus behind industrial policy, the focus in the wind industry had been on speed and upscaling, rather than on quality and basic research (Gosens and Lu 2013; Kirkegaard 2015). However, pragmatically allowing the 'quality crisis' to emerge laid bare some of the inherent weaknesses of technology and knowledge transfer. Indeed, since 2004, 'indigenous innovation' has become institutionalised as part of China's doctrine of 'Scientific Development' (Kirkegaard 2015). The quality crisis however shed light on the limitations of such capabilities, and in turn emphasized both the need to develop indigenous innovation capabilities in core technologies, and the need for basic research. This then adversely impacted on Sino-Foreign and Sino-Danish supply chain relations, resulting in power struggles over access to key technologies, such as software algorithms (Kirkegaard 2015). The 'turn to quality' around 2012/13 that had been envisaged through STI policies is a trend that continues to today, where an enhanced focus on indigenous and open innovation, alongside open cooperation, is being reiterated. This was clearly reflected in Xi Jinping's speech to scientists in September 2020 where he argued that China must continue to accelerate technological innovation and promote quality, for example by strengthening basic research (Xinhua, $11^{\text {th }}$ Sep. 2020). Interestingly, a major strategy is to ensure that [China] "strengthens international scientific and technological cooperation. China needs to be more proactive in integrating into the global innovation network and enhance our technological innovation capabilities through open cooperation. The more we face the blockade and suppression, the less China can engage in self-enclosure and self-isolation. Instead, China must implement a more open, inclusive, mutually beneficial and shared international science and technology cooperation strategy". On the one hand, China is persisting in seeking to improve its capacity for independent (indigenous) innovation, laying the foundation for sound international collaboration, while, on the other hand, it recognizes "it is necessary to promote international scientific and tech- nological exchanges and cooperation with more open thinking and measures. Under the current situation, it is necessary to pragmatically promote international scientific and technological cooperation". This is exactly what produced the somewhat antagonistic forces of simultaneous competition and collaboration during the 'turn to quality'.

However, we note the reiteration of the need for more open innovation and basic research in core technologies to move China towards 'the quality, originality, and contribution of research' (NDRC 2016, p.1) as a signal that Sino-Foreign and Sino-Danish collaboration may enjoy a bright(er) future. Indeed, the 'turn to quality' has made Sino-Danish supply chain relations more stable as Danish and Chinese companies increasingly compete on a more level playing field, rather than competing against each other based on divergent criteria (quantity/price versus quality/innovation). When the criteria are moving together towards a focus on quality, it may be easier to collaborate in a Chinese market that is rapidly evolving. The joint focus on quality, such as ensuring optimal and stable energy output, and optimal system integration, should stimulate new joint focus areas and may bode well for enhanced collaboration. At the same time, as Chinese actors have rapidly upgraded, Western companies may increasingly be able to learn from Chinese companies, for example, in terms of implementing effective 'cost-out' strategies and accelerating innovation processes (but without jeopardizing quality); that is, there may be new and exciting opportunities for Western turbine manufacturers, component suppliers and research institutes to learn from Chinese partners in striking a new balance between the Chinese trial-and-error approach and price-focused strategy of accelerated learning, versus the Western more risk-adverse and certification-focused strategy (Kirkegaard 2019). Indeed, we could claim that Denmark and 'the West' have something to learn from China in terms of industry development; ensuring rapid upgrading through pragmatic experimentalism. This would have to take place within an entirely different political context, and the social, environmental and economic costs should be evaluated against the potential for rapid development and learning.

In summary, while the current global political backdrop is marked by increasingly strained China-US and China-EU ties, and an external environment characterised by rising protectionism from both the US and China, at the same time as we are facing a global economic downturn, China has sent a clear signal with President Xi Jinping's speech on Chinese Science \& Technology Policy in September 2020. We believe, given the strong background in diplomatic, research and business collaboration between China and Denmark, and taking China's upgrading into account, there is hope for enhanced collaboration in the future, while being mindful of issues of IPRs and other trade-related and political-economic concerns. 


\section{References}

Andrews-Speed, P. 2012 The Governance of Energy in China. Transition to a Low-Carbon Economy, Palgrave Macmillan, Basingstoke.

Bloomberg (New Energy Finance). 2012. Will China's New Renewable Portfolio Standard Boost Project Development?' Renewable energy: Research note, 11 May.

Breznitz, D. and Murphree, M. 2011. Run of the Red Queen: Government, Innovation, Globalization, and Economic Growth in China. New Haven: Yale University Press.

Cao, C. 2004. 'Chinese Science and the "Nobel Prize Complex"', Minerva 42: pp. 151-172.

Cherni, J. A. and Kentish, J. 2007. 'Renewable Energy Policy and Electricity Market Reforms in China', Energy Policy 35: pp. 3616-3629.

Christensen, N. H. 2013. Shaping markets: A neoinstitutional analysis of the emerging organizational field of renewable energy in China. PhD thesis, Department of Business 8 Politics, Copenhagen Business School.

Chung, S-w. W. and Xu, Q. 2016. China's Energy Policy from National and International Perspectives - The Energy Revolution and One Belt One Road Initiative. City University of Hong Kong Press, Hong Kong.

Communist Party of China Central Committee and the State Council. 2015. 关于进一步深化电力体制改革的若 干意见, 中发(2015)9号文' 全文 ['Several Opinions of the CPC Central Committee and the State Council on Further Deepening the Reform of the Electric Power System', No. 9 Text Full Text], 'Energy Revolution' ('Policy \#9'/'Document No. 9'), 15 March 2015, http://www.ne21.com/news/show64828.html

Delman, J. 2020. 'Policy Translation and Energy Transition in China'. Chapter 10 in J. Meng and S. Laviosa (eds.) The Oxford Handbook of Translation and Social Practices, New York: OUP.

Dupuy, M. 2016. 'China Power Sector Reform: Key Issues for the World's Largest Power Sector'. The Regulatory Assistance Program (RAP), March 2016, viewed 8 December 2016, https://www.raponline.org/wp-content/ uploads/2016/07/rap-dupuy-key-issues-china-powersector-2016-march.pdf.

Danish Energy Agency. n.d.. Important long-term energy cooperation with China, https://ens.dk/en/our-responsibilities/global-cooperation/country-cooperation/china

Ernst, D. 2008. 'Asia's "upgrading through innovation" strategies and global innovation networks: an extension of Sanjaya Lall's research agenda'. Transnational Corporations, 17(3): pp. 31-57.

Ernst, D. 2013. Standards, Innovation, and Latecomer Economic Development: A Conceptual Framework. East-West
Center Working Papers. Economics Series, No. 134

Fan, C. C. 2006. 'China's Eleventh Five-Year Plan (20062010): From "Getting Rich First" to "Common Prosperity"'. Eurasian Geography and Economics, 47(6): pp. 708-723.

García, C. 2013. 'Policies and Institutions for Grid-Connected Renewable Energy: "Best Practice" and the Case of China'. Governance: An International Journal of Policy, Administration, and Institutions, 26(1): pp. 119-146.

Gosens, J. and Lu, Y. 2013. 'From Lagging to Leading? Technological Innovation Systems in Emerging Economies and the Case of Chinese Wind Power', Energy Policy 60: pp. 234-250.

Gosens, J. and Lu, Y., 2014, 'Prospects for Global Market Expansion of China's Wind Turbine Manufacturing Industry', Energy Policy 67: pp. 301-318.

GWEC. 2020. 'Global Wind Report - Annual Market Update 2019', Global Wind Energy Council.

Haakonsson, S., Kirkegaard, J. K., and Lema, R. 2020. The decomposition of innovation in Europe and China's catchup in wind power technology: the role of KIBS. European Planning Studies: pp. 1-19.

Kirkegaard, J. K. 2015. Ambiguous Winds of Change Or Fighting Against Windmills in Chinese Wind Power Mapping Controversies over a Potential Turn to Quality in Chinese Wind Power, PhD thesis, Department of Business \& Politics, Copenhagen Business School.

Kirkegaard, J. K. 2017. 'Tackling Chinese Upgrading Through Experimentalism and Pragmatism: The Case of China's Wind Turbine Industry', Journal of Current Chinese Affairs, 46(2): pp. 7-39.

Kirkegaard, J. K. 2019. Wind Power in China - Ambiguous Winds of Change in China's Energy Market. Routledge: New York.

Kirkegaard, J. K. and Caliskan, K. 2018. 'When Socialists Marketize: The Case of China's Wind Power Market Sector', Journal of Cultural Economy, 12(2): pp. 154-168.

Klagge, B., Liu, Z. and Silva, P. C., 2012, 'Constructing China's Wind Energy Innovation System', Energy Policy, 50: pp. 370-382.

Korsnes, M. 2014. 'Fragmentation, Centralisation and Policy Learning: An Example from China's Wind Industry'. Journal of Current Chinese Affairs, 43(3): pp. 175-205.

Kroeber, A. R. 2016. China's Economy - What Everyone Needs to Know, Oxford University Press, New York.

Lardy, N. R. 2016. 'The changing role of the private sector in China'. Reserve Bank of Australia Research Discussion Papers. 
Lema, A. and Ruby, K. 2007. 'Between fragmented authoritarianism and policy coordination: Creating a Chinese market for wind energy'. Energy Policy, 35: pp. 3879-3890.

Lewis, J. I. 2007. 'Technology Acquisition and Innovation in the Developing World: Wind Turbine Development in China and India'. St. Comp. Int. Dev., 42: pp. 208-232.

Lewis, J. I. 2013. Green Innovation in China. China's Wind Power Industry and the Global Transition to a Low-Carbon Economy, Columbia University Press, New York.

Lewis, J. I. and Wiser, R. H. 2007 'Fostering a Renewable Energy Technology Industry: An International Comparison of Wind Industry Policy Support Mechanisms', Energy Policy 35: pp. 1844-1857.

Lieberthal, K. 2004. 'The Organization of Political Power and its Consequences: The View from the Outside', in K. Lieberthal (ed.), Governing China: From Revolution through Reform, pp. 171-205. W.W. Norton \& Co, New York.

Liu, Y. and Kokko, A. 2010, 'Wind power in China: Policy and development challenges'. Energy Policy, 38: 5520-5529.

Liu, X. and Kong, L., 2016, 'A New Chapter in China's Electricity Market Reform', Energy Studies Institute, Policy brief, March 212016.

Mathews, J. A. 2002. 'Competitive Advantages of the Latecomer Firm: A Resource-Based Account of Industrial Catch-Up Strategies'. Asia Pacific Journal of Management, 19: pp. 467-488.

Mathews, J. A. and Tan, H. 2015. China's Renewable Energy Revolution, Palgrave Macmillan, New York.

Mathews, J. A. 2016, 'China's Continuing Renewable Energy Revolution - Latest Trends in Electric Power Generation', The Asia-Pacific Journal, Japan Focus 14(17).

Meidan, M., Andrews-Speed, P. and Xin, M. 2009. 'Shaping China's Energy Policy: Actors and Processes', Journal of Contemporary China 18(61): pp. 591-616.

MOST (Ministry of Science and Technology of the People's Republic of China). 2006. State Council, 国家中长期科学 和技术发展规划纲要 (2006-2020) [National Outline for Medium and Long Term Science and Technology Development (2006-2020)], 9 February 2006, http://www.gov. cn/jrzg/2006-02/09/content_183787.htm.

MOST (Ministry of Science and Technology of the People's Republic of China). 2012. State Council, The Central People's Government of the People's Republic of China, 关 于印发风力发电科技发展'十二五'专项规划的通知 ['The 12th Five-Year Plan for the Scientific and Technological Development of Wind Power], 国科发计,197号, National Branch No. 197, 24 April 2012, http://www.most.gov.cn/fggw/ zfwj/zfwj2012/201204/t20120424_93884.htm.

MOST (Ministry of Science and Technology). 2019. Opinion of the Party Committee of the Ministry of Science and Technology of the Communist Party of China on the guidance of Xi Jinping 's new era of socialism with Chinese characteristics as a guide to join forces and enter the ranks of innovative countries (2019-01-21) 中共科学技术部 党组关于以习近平新时代中国特色社会主义思想为指导凝 心聚力决胜进入创新型国家行列的意见(2019-01-21)

Nahm, J. and Steinfeld, E. S. 2014. 'Scale-Up Nation: China's Specialization in Innovative Manufacturing', World Development, 54: pp. 288-300.

Naughton, B. 2017. 'Is China Socialist?', Journal of Economic Perspectives 31(1): pp. 3-24.

NDRC (National Development and Reform Commission). 2007. Medium and Long-Term Development Plan for Renewable Energy in China, September. http://www.chinaenvironmentallaw.com/wp-content/uploads/2008/04/ medium-and-long-term-development-plan-for-renewable-energy.pdf.

NDRC (National Development and Reform Commission) 2016. The 13th Five-Year Plan for Economic and Social Development of the People's Republic of China (20162020), transl. Central Committee of the Communist Party of China, Beijing, China, http://en.ndrc.gov.cn/newsrelease/201612/PO20161207645765233498.pdf.

NEA (National Energy Administration) of the National Development and Reform Commission. 2015. 国家发展改 革委 国家能源局关于改善电力运行调节促进清洁能源多 发满发的指导意见 发改运行[2015]518号 [The NEA of the NDRC's Guiding Opinions on Improving Electric Power Operation Regulations and Promoting the Reform of Full Release of Clean Energy Development and Operation, No. 518], September 2015 http://www.nea.gov.cn/201504/09/c_134136821.htm.

O'Connor, G. C. 2006. 'Open, Radical Innovation: Toward an Integrated Model in Large Established Firms', in $\mathrm{H}$. Chesbrough, W. Vanhaverbeke and J. West (eds.), Open Innovation. Researching a New Paradigm, Oxford University Press, New York.

Silva, P. C. and Klagge, B. 2013. 'The Evolution of the Wind Industry and the Rise of Chinese Firms: From Industrial Policies to Global Innovation Networks'. European Planning Studies, 21(9): pp. 1341-1356.

Strambach, S. 2008. Knowledge-intensive business services (IKIBS) as drivers of multilevel knowledge dynamics. International Journal of Services Technology and Management, $10(2 / 3 / 4)$.

Williamson, P. J. and Yin, E. 2014. 'Accelerated Innovation: The New Challenge from China', MIT Sloan Management Review, Research Feature, 23 April.

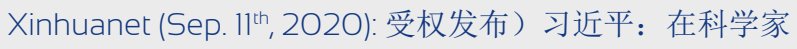
座谈会上的讲话 (President Xi Jinping's speech at scientists' symposium 11th Sep 2020), http://www.xinhuanet. com/politics/leaders/2020-09/11/c_1126483997.htm

Zhao, X., Wang, F. and Wang, M., 2012, 'Large-Scale Utilization of Wind Power in China: Obstacles of Conflict between Market and Planning', Energy Policy 48, 222-232 